\title{
A Model Intervention Program for Secondary School Education
}

\author{
Brian Gerber ${ }^{1}$ and Edmund A. Marek ${ }^{2}$ \\ ${ }^{1}$ James L. and Dorothy H. Dewar College of Education, Valdosta State University, 1500 N. Patterson Street, Valdosta, \\ GA 31698, USA \\ ${ }^{2} J o h n$ W. Renner Science Education Center, Jeannine Rainbolt College of Education, The University of Oklahoma, Norman, \\ OK 73072, USA
}

Correspondence should be addressed to Edmund A. Marek, eamarek@ou.edu

Received 28 December 2011; Revised 29 January 2012; Accepted 20 February 2012

Academic Editor: Susan Hallam

Copyright () 2012 B. Gerber and E. A. Marek. This is an open access article distributed under the Creative Commons Attribution License, which permits unrestricted use, distribution, and reproduction in any medium, provided the original work is properly cited.

\begin{abstract}
Valdosta State University and the Valdosta City Schools (Valdosta, GA) partnered in 2008 to form the Valdosta Early College Academy (VECA). VECA epitomizes the early college concept of (a) admitting underperforming students with multiple risk factors for dropping out of school (e.g., low socioeconomic status, minority, and first-generation high school or college) and (b) providing college level dual enrollment courses. VECA is very different than nearly every other early college school in the nation. Most (85\%) of the 200 early colleges currently operating in the United States begin with students in the 9th grade. Nearly all of the remaining early colleges begin with 7th grade; only a few are 6-12-grade schools. VECA targets two primary priorities, (a) innovations that complement the implementation of higher standards and high-quality assessments and (b) innovations that support college access and success. The primary purpose of this paper is to chronicle the genesis and development of VECA. This program is very successful, replete with research opportunities, and represents a model early college program. We plan to continue to grow VECA to ultimately include grades six through twelve and to research that growth and development.
\end{abstract}

\section{Introduction and Background}

Soon after taking office, President Barack Obama articulated in speeches and solidified in policy what Americans already sensed: achieving some form of education or training beyond high school with a one-year certificate, two-year Associate's degree, or four-year Bachelor's degree is critical to our country future. Unfortunately, this goal of postsecondary education is nearly impossible for a large proportion of students across this country, especially minority students, those from low socioeconomic households, and English language learners. We are developing a model program to address this goal at the state level.

Recent state and national reports verify the academic deficiencies in one southeastern state, namely, Georgia (GA), particularly rural South Georgia. Of the 52 jurisdictions (50 states plus the District of Columbia and Department of Defense schools) participating in the 2009 mathematics assessment, Georgia 8th graders scored significantly lower than those in 33 jurisdictions [1]. This performance is consistent with reading scores in which Georgia 8th graders scored significantly lower than those in 33 jurisdictions [2]. Similarly, of the 45 jurisdictions (44 states and Department of Defense schools) participating in the 2005 science assessment, Geor-gia 8th graders scored significantly lower than those in 27 jurisdictions [3]. Compounding these deficiencies is evidence that Black students scored significantly lower than their White counterparts and students eligible for free/reduced lunches scored significantly lower than those not eligible.

A high minority population and low socioeconomic status characterize South Georgia, which is the location of the model program described in this paper. Valdosta City Schools (VCSs) include 76\% Black students and 17\% White students (the remainder Asian or Hispanic). Approximately $76 \%$ of all VCS students are eligible for free or reduced lunches [4]. Graduation rates for the two recent years exemplify the need for a program within the VCS that shows promise in reducing the sizeable gap that exists between Black and White students. For 2006-2007, the graduation rate of 
White students stood at $77.9 \%$ compared to Black students at $49.7 \%$. The following year showed a sharp rise in the White student graduation rate to $87.6 \%$ with a much smaller rise in the Black student graduation rate to only $53.4 \%$.

\subsection{Strength of Research, Significance of Effect, and Magnitude} of Effect. The early college high school initiative began in 2002 with three schools. By 2009, nearly 42,000 students were enrolled in 200 early college schools across 24 states. Data are becoming available to support further research and expansion of the early college concept. Early college schools initiatives serve students underrepresented in higher education, primarily low-income students and students of color. In 2008-2009, 74\% of early college enrollments were students of color, $56 \%$ were eligible for free or reduced lunch, and 10\% were English-language learners. Preliminary data suggest that: (a) higher percentages of early college students are graduating compared with high school students nationally, (b) early college graduates have higher college attendance rates than other high school graduates, and (c) a higher proportion of early college graduates are enrolling in four-year colleges, which may promote higher completion rates as well, based on degree attainment patterns at higher education institutions [5].

Early college students fare better than national averages in high school graduation rates. The four-year graduation rate for early college schools for 2008 was approximately $92 \%$. Owing to inconsistent data gathering across states, it is difficult to arrive at a comparative national rate, but $E d u$ cation Week's Diplomas Count 2009 identified a national graduation rate for 2005-2006 of 69\%. Various reports have estimated national four-year graduation rates ranging from about 70 to $83 \%$. In light of the fact that over half of the students attending early college schools are eligible for free or reduced lunch, the graduation rates achieved by students at the schools are particularly impressive. The National Center for Education Statistics reported that, based on national averages in 2005 and 2006, students from low-income families are approximately four times as likely as those from high-income families to drop out of high school [6].

Forty percent of graduates attending early college schools operating for at least four years earned more than one year of college credit prior to high school graduation. These students may be more likely than traditional high school graduates without credit to complete a college degree. In The Toolbox Revisited, Adelman [7] found that traditional first year college students who earn at least 20 credits during their first year are more likely to complete a degree. While early college students are not technically in their first year of college, many enter college with the knowledge that they have successfully completed a year of college work, and it appears likely that many of these students will go on to earn a bachelor's degree. In a study conducted in Florida and New York, Karp et al. [8] found that students who took college courses in high school were more likely to receive a high school diploma, enroll in college, and persevere in college compared to students without college experience. The study reported that, in many cases, the benefit of dual enrollment was greater for low-income students than for their counterparts.

Eighty-three percent of early college graduates earned some college credits, indicating they gained concrete knowledge about what it takes to succeed in postsecondary education [5]. The National Center for Education Statistics [9] found accumulation of college credits while in high school it is much lower nationally; only $17 \%$ of high school graduates in the USA enter higher education having earned college credit in high school. Early college graduates achieved higher rates of attending college than their counterparts. Eighty-nine percent of early college graduates in 2008 went to some form of postsecondary education. Nationally, $66 \%$ of all high school graduates in 2006 enrolled in college immediately after high school [9]. Again, compared with national averages, a higher percentage of early college students are students of color and from low-income families, which makes these college attendance rates even more striking.

Early college graduates are more likely than their peers to attend four-year institutions. Of the early college students who enrolled in postsecondary education after graduating in 2008, about $60 \%$ attended four-year institutions, $36 \%$ attended two-year colleges, and $4 \%$ enrolled in certificate or other programs of fewer than two years. Nationally, about $44 \%$ of beginning postsecondary students attended four-year colleges and universities, $48 \%$ attended two-year institutions, and $8 \%$ attended certificate or other programs of fewer than two years [10]. Given that completion rates are significantly higher at four-year institutions than at two-year colleges, these comparisons suggest that early college students will be more likely to complete a degree than their peers.

1.2. VECA. In response to these unfavorable data, Valdosta State University (VSU) and the Valdosta City Schools partnered in 2008 to form the Valdosta Early College Academy (VECA). We started with 36 sixth-grade students, and, as they transitioned to seventh-grade, a new class of 36 sixthgraders (two classrooms of 18 students each) was added in Fall 2009. Currently, VECA is a 6-7-grade school with 72 students, 4 teachers, and a principal located within the Dewar College of Education building at VSU. The school epitomizes the early college concept of admitting underperforming students with multiple risk factors for dropping out of school (e.g., low socioeconomic status, minority, and firstgeneration high school or college) and providing college level dual enrollment courses for them by the 11th grade. Yet, VECA is very different than nearly every other early college school in the nation. Most $(85 \%)$ of the 200 early colleges currently operating in the United States begin with students in the 9th grade. Nearly all of the remaining begin with 7th grade; only a few are 6-12-grade schools.

VECA targets two primary priorities, (a) innovations that complement the implementation of higher standards and high-quality assessments and (b) innovations that support college access and success. We plan to continue to grow VECA to ultimately include grades six through twelve. Table 1 contains the goals and objectives for the project along with project design strategies to achieve the goals. 
TABLE 1: Quantitative and qualitative evaluation of goals in relation to program objectives.

Goal 1. Expand Valdosta Early College Academy (VECA) from a 6-7 grade school to 6-12.

Objective 1.1: Add a new entering 6th grade every year so that VECA will be a 6-12 grade school by the 2014-15 academic year.

Objective 1.2: Support an enrollment of at least 250 students by 2014-15 academic year.

Objective 1.3: Locate VECA on or near the college campus with appropriate facilities.

\begin{tabular}{|c|c|c|}
\hline Benchmarks & Outcomes & Activities and methods \\
\hline $\begin{array}{l}\text { (1) Establish rigorous application process for } \\
\text { each new class of } 36 \text { sixth-grade students } \\
\text { accepted into the program; majority will be } \\
\text { several grades behind in some academic areas, } \\
\text { come from low socioeconomic status families, } \\
\text { racial and ethnic minorities, English language } \\
\text { learners, and first-generation high school } \\
\text { graduates and/or college attendees. }\end{array}$ & $\begin{array}{l}\text { (1) Maintain 6th grade classes in the Dewar } \\
\text { College of Education (COE) on the campus of } \\
\text { VSU and move the other grades (due to space } \\
\text { limitation in the COE) to a recently vacated } \\
\text { school } 1 \text { block from the COE (see Goal 2). }\end{array}$ & $\begin{array}{l}\text { (1) Recruit Participants. } \\
\text { (2) Use some rooms within the vacated } \\
\text { school for COE classes so that VECA } \\
\text { students are in regular contact with } \\
\text { university students and faculty. } \\
\text { (3) Actuarial data on recruitment, } \\
\text { participation, program retention. }\end{array}$ \\
\hline
\end{tabular}

Goal 2. Improve student achievement in all content areas.

Objective 2.1: Using a matched comparison group design, VECA students will outperform by $25 \%$ over the life of the project a like group of students within the same district in all subjects (mathematics, science, language arts, and social studies).

Objective 2.2: Eliminate by the end of 10th grade the gap in achievement in all subject areas (mathematics, science, language arts, and social studies) between White students within the district and Black students within VECA.

\section{Benchmarks}

(1) Establish procedures for recruiting and retaining staff that know their subjects well with a record of increasing student achievement.

(2) Provide frequent and substantive professional development through VSU, professional organizations, and partnering with the Teacher Resource Network/The Teacher Channel in Atlanta, Georgia. (3) Focus classroom strategies around inquiry-oriented, standards-based, collaborative group work that differentiates instruction and places learning in the context of students' daily lives.

(4) Provide regular assistance in every classroom with VSU students (the COE has 3,500 teacher candidates and each requires 900 hours of field work in education settings). (5) VSU students (e.g., teacher candidates, counselor education students) will be included in VECA classrooms $75 \%$ of the time.

(6) Partnerships will be formed with the Honors Program on campus; Black sororities and fraternities; VSU football and men's and women's basketball teams; local community groups, such as a chapter of the 100 . Black Men of Valdosta, will also spend time in the classroom and provide tutoring, lead extracurricular activities, and be positive role models.

\section{Outcomes}

(1) Over the life of the project the percentage of students in the "meets" and "exceeds" categories for Criterion-Referenced Competency Tests (CRCT) administered in middle school and "pass" and "pass plus" categories for high school End-of-CourseTests (EOCT) and the Georgia High School Graduation Test (GHSGT) will increase by $25 \%$.

(2) Achievement gap measures will utilize the percentage of students in the "meets" and "exceeds" categories for CRCT and "pass" and "pass plus" categories of EOCT and GHSGT.

(3) Field trips, clubs, and college site visits will be provided every year.

(4) A summer enrichment program will be established.

. (5) Community service will be required with five hours of service in 6th grade and 5 additional hours each year through 12th grade (i.e., 10 hours for 7 th graders, 35 hours for 12th graders).

(6) Achieve a student attendance rate of $95 \%$.

(7) Hire full-time Guidance Counselor (see Goal 3).

(8) Hire full-time Instructional Technologist (see Goal 3).

(9) Hire full-time Community Involvement Coordinator (see Goal 3).

(10) Each year hold a Community Service Forum, open to the public, where students present a summary of their service and explain its benefits to the community and themselves.
Activities and methods

(1) Travel enhances classroom instruction providing opportunities for experiential learning, practice appropriate social skills in various settings, experience diverse occupations, and opportunities to visit postsecondary institutions outside the regional area.

(2) Summer enrichment program to include engaging one week academic camp on VSU campus led by university faculty and VECA teachers through projects, activities, and competitions; on-line programs with a research base and aligned with the Georgia Performance Standards (e.g., Study Island); independent project-based activities centered around student interests (e.g., interview family for genealogy project, document summer vacation); a required summer book reading club.

(3) Numerous opportunities exist for service; environment (e.g., local recycling centers, Georgia Geological Survey, Nature Conservancy); education (e.g., area schools and libraries, VSU); community (e.g., Habitat for Humanity, Second Harvest Food Bank, area churches and nursing homes, Veterans of Foreign Wars).

(4) Actuarial attendance data.

(5) Actuarial data on academic competitions, awards, and extracurricular activities.

(6) Relationship of the above actuarial data with CRCT, EOCT, and GHSGT scores. (7) Surveys. 
TABle 1: Continued.

Goal 3. Improve high school graduation and college enrollment rates.

Objective 3.1: Increase the on-time high school graduation rate to at least $95 \%$ as measured by number of students entering their freshman year of VECA and graduating within four years.

Objective 3.2: Decrease the dropout rate to $1 \%$ as measured by the number of students entering VECA as 6th graders and leaving school prior to graduation.

Objective 3.3: 75\% of VECA students will successfully complete college level coursework prior to high school graduation.

Objective 3.4: 95\% of VECA students will attend postsecondary education as measured by the number of students accepted to an institution of higher education.

\begin{tabular}{ll} 
Benchmarks & Outcomes \\
\hline $\begin{array}{l}\text { (1) Use highly effective teachers, support } \\
\text { from VSU students, and enrichment through } \\
\text { summer activities and travel to accelerate }\end{array}$ & $\begin{array}{l}\text { (1) Hire full-time Guidance Counselor to } \\
\text { facilitate individual student academic } \\
\text { program planning; interpret cognitive, }\end{array}$ \\
$\begin{array}{l}\text { academic achievement of VECA students } \\
\text { such that they are prepared for dual }\end{array}$ & $\begin{array}{l}\text { students with attendance or disciplinary } \\
\text { enrollment college courses by the 11th grade. }\end{array}$ \\
$\begin{array}{l}\text { issues; maintain student records; analyze } \\
\text { disaggregated assessment data; facilitate }\end{array}$ \\
$\begin{array}{l}\text { of resources between VSU and VECA. } \\
\text { Currently, VECA students have completed }\end{array}$ & $\begin{array}{l}\text { college visits; work with VSU on dual } \\
\text { enrollment for VECA 11th and 12th grade }\end{array}$ \\
$\begin{array}{l}\text { music and art programs led by VSU } \\
\text { professors and music and art teacher }\end{array}$ & $\begin{array}{l}\text { students; assist students and parents with } \\
\text { college applications and financial aid }\end{array}$ \\
pandidates; physical education classes led by & paperwork.
\end{tabular}

VSU faculty and PE teacher candidates; symphony, a variety of sporting events, and guest speakers.

(3) Increase opportunities on the VSU campus with notable addition being receipt of a library card providing privileges with interlibrary loan and access to a vast amount of e-based and print resources (currently 500,000 bound volumes, 2,000 current periodicals and newspapers, over 4,00 e-journals and 50,000 e-books, 8,000 videos and 10,000 music CDs, and growing).

(4) Continue bimonthly VECA Advisory Board meetings resulting in fund raising initiatives outlined in sustainability section. (5) Develop VECA Policies and Procedures Guide to be provided to all VECA students and families. The guide will contain necessary forms required by the district (e.g., immunization, photo release, and proof of residency); information about the daily working of the school (e.g., calendar, daily periods, tutoring, after school activities, and lunches); information on VSU and accelerated funding.
Activities and methods

(1) Continue the VECA Advisory Board consisting of the Director of the Early College Program from the University System Board of Regents; Valdosta City School Board member; two representatives each from the Parent Teacher Organization and VECA Student Government Association; key personnel from VSU (Provost, COE Dean, Director of Advising, Middle and Secondary Education Dept. Head, and Dir.

of Curriculum, Instruction and Outreach); VCS (Superintendent, Asst. Super. for Finance, Curriculum Director, Professional Learning and Research Coordinator, and PR Director); and community (Mgr., Georgia Power; Pres., Georgia Gulf Sulfur; Pres., Valdosta/Lowndes County Chamber of Commerce; Pres., Hunt Industries; Dir. of Sales and Community Development, Park Avenue Bank; Chief Financial Officer and Chief Operating Officer, South Georgia Medical Center; Engineer, Georgia Power; VP and Dir. of Human Resources, Langdale Industries; Dir. of Personnel, Langdale Forest Products; Pres., US Press; General Manager, Wild Adventures theme park).

(2) The Accelerated Program is operated through the Georgia Student Finance Commission and is for students classified as high school juniors and seniors. The program allows students to pursue postsecondary study at approved public and private colleges and tech. colleges while receiving dual high school and college credit for courses successfully completed. Courses are available in areas of the core graduation requirements for college preparatory students: English; mathematics; social studies; science; foreign lang. The program pays tuition, mandatory fees and provides students with a book allowance. (3) Actuarial data on enrollment, completion, and attrition.

(4) Course performance.

(5) Surveys. 


\section{VECA Data: Preliminary Results and Discussion}

Valdosta Early College Academy has been in existence for nearly three years and has standardized assessment data for the first cohort of 36 students that entered as 6th graders and tested in the spring of 2009 (2010 data are not yet available). Baseline data of 5 th grade test scores were used to compare VECA student academic progress with a matched comparison student group equivalent in ethnicity, gender, socioeconomic status, and feeder school.

In 2009 a significant difference was found between the English/Language Arts Criterion-Referenced Competency Tests score of 6 th grade VECA students $(\mathrm{M}=835.39, \mathrm{SE}=$ 2.751 ) and the 6th grade students who "match" the VECA students in the Valdosta City Schools $(\mathrm{M}=830.61, \mathrm{SE}=$ 2.198). (The comparison group of 6 th graders was selected using matching traits for students (e.g. gender, ethnicity, and social-economics) from the local schools.) The difference was significant, $\mathrm{t}(72.856)=-1.358, P<.05$, with an effect size of 0.22 . VECA 6 th graders also outperformed the matched comparison group in science, mathematics, social studies, and reading, but not to a significant level. However, the trend is very clear. VECA is producing achievement gains with students that surpass those within the traditional school. Currently, no time series research is available that includes matched comparison groups with early college students beginning in 6th grade. Nearly all research begins with 9th grade early college students. Our plan is to follow these students throughout the program, beginning with 6th graders, which likely will provide valuable insight on the critical period for initiating the early college experience.

The above research findings support the goals of this program, which will test the following hypotheses.

Hypothesis I: students attending VECA will graduate at high rates and be more likely to attend postsecondary education.

Hypothesis II: students entering the early college experience in the 6th grade will demonstrate an elimination of racial gaps during high school.

Hypothesis III: There is a critical period for initiating the early college experience that will maximize improved educational outcomes such as standardized testing performance, graduation rates, dual enrollment, and success in postsecondary education.

\section{Endnote}

The following descriptions of VSU, its College of Education, and the community of Valdosta are included to give perspective of the partners of VECA. Valdosta State University, founded in 1906, is the second largest university in Georgia south of the Atlanta area. VSU enrolls over 12,000 students and is located in Valdosta, a metropolitan city surpassing 50,000 inhabitants. VSU has a mission to serve an expansive rural area of South Georgia including 41 counties, stretching from the Atlantic Ocean to the Alabama state line and encompassing one-third of the geographical region of the state. The Dewar College of Education (COE) at VSU (a) is one of 16 in the University System that has state-approved educator preparation programs, (b) is accredited by the National Council for Accreditation of Teacher Education, and (c) has nearly 3,500 education majors. The COE is committed to provide and educate effective teacher professionals and established a definition for evidence-based practices which provides the foundation of our mission: evidencebased practices are grounded in professional wisdom and/or systematic inquiry and, when properly implemented in appropriate settings, have been demonstrated to positively impact teaching and learning. Shavelson and Towne [11] indicated that the evidence base in education necessitates a variety of methodologies to address a variety of questions, and the faculty members and stakeholders in the Dewar College of Education believe that a variety of approaches are necessary to encompass evidence-based practices.

The COE has a nationally recognized science teacher professional development program, Learning through Inquiry Science and Technology (LIST), which was granted the most Outstanding Staff Development Award in 2003 by the Florida Staff Development Association. Then, in 2004, the American Association of State Colleges and Universities named the COE the Christa McAuliffe Award recipient for documented impact on K-12 student achievement with nearly 500 teachers and 400,000 students impacted to date with the LIST Project.

The administration, faculty, and students of VSU embrace the Valdosta Early College Academy. In addition to the over 150 faculty members, the Dewar College of Education at VSU has nearly 3,500 teacher candidates, each requiring over 900 hours of field experience. On average, every day, there are two teacher candidates in each of the four VECA classrooms all day assisting students one-on-one, in small groups, or with the whole class based on teacher and student needs. We plan to broadly disseminate the accomplishments of the Valdosta Early College Academy and its unique program model in order to support further development or replication.

\section{References}

[1] National Center for Education Statistics Student Effort and Educational Progress, Table 24.1 "Transition to College," derived from U.S. Department of Commerce, Census Bureau, Current Population Survey, October Supplement, 1972-2006, http://nces.ed.gov/nationsreportcard/pdf/stt2009/2010454 GA8.pdf.

[2] http://nces.ed.gov/nationsreportcard/pdf/stt2009/2010460 GA8.pdf.

[3] http://nces.ed.gov/nationsreportcard/pdf/stt2005/ 2006467GA8.pdf.

[4] Georgia Department of Education, District Data Report Cards, 2010, http://archives.gadoe.org/ReportingFW.aspx?PageReq $=102 \&$ CountyId $=792 \& \mathrm{~T}=1 \& \mathrm{FY}=2011$.

[5] T. Nodine, Innovations in College Readiness. Jobs for the Future, Boston, Mass, USA, 2009.

[6] J. Laird, Dropout and Completion Rates in the United States 2006, National Center for Education Statistics, Washington, DC, USA, 2008. 
[7] C. Adelman, The Toolbox Revisited: Paths to Degree Completion from High School through College, Department Education, Washington, DC, USA, 2006.

[8] M. Karp, J. Calcagno, K. Hughes, D. Jeong, and T. Bailey, The Postsecondary Achievement of Participants in Dual Enrollment : An Analysis of Student Outcomes in Two States, National Research Center for Career and Technical Education, University of Minnesota, St. Paul, Minn, USA, 2007.

[9] 2004/06 Beginning Postsecondary Students Longitudinal Study Data Analysis System, National Center for Education Statistics, Washington, DC, USA.

[10] L. Berkner and S. Choy, Descriptive Summary of 2003-04 Beginning Postsecondary Students: Three Years Later, National Center for Education Statistics, Washington, DC, USA, 2008.

[11] R. J. Shavelson and L. Towne, Scientific Research in Education, National Research Council, National Academy Press, Washington, DC, USA, 2002. 


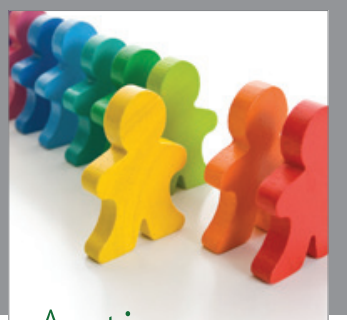

Autism

Research and Treatment
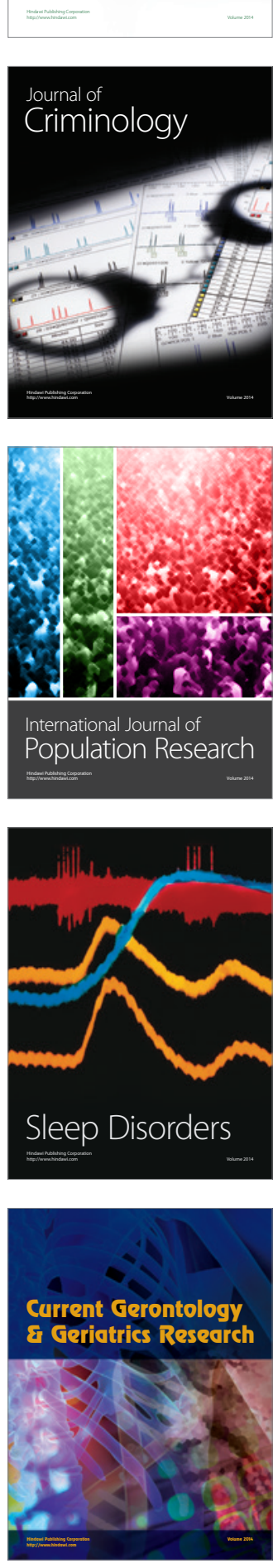
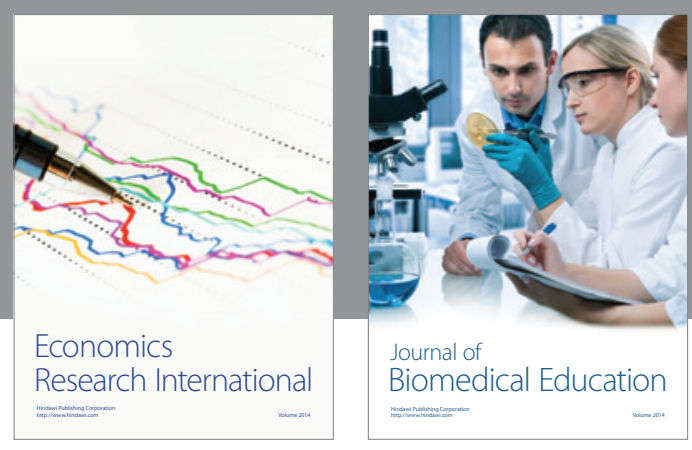

Journal of

Biomedical Education

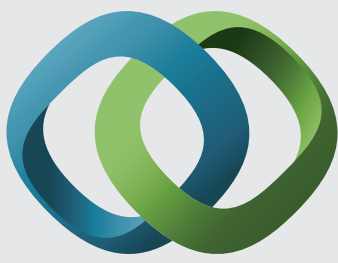

\section{Hindawi}

Submit your manuscripts at

http://www.hindawi.com
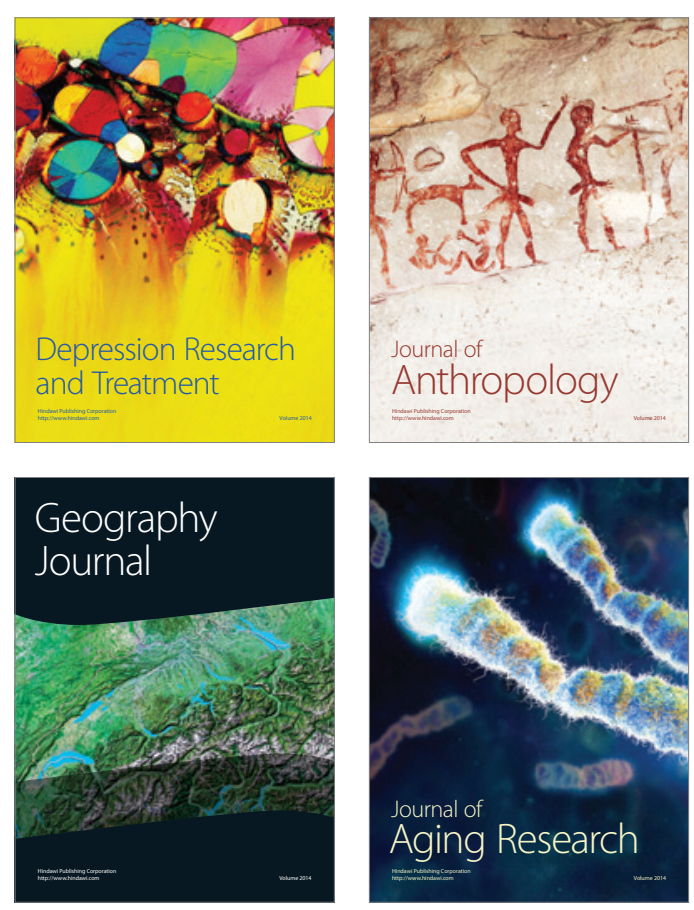

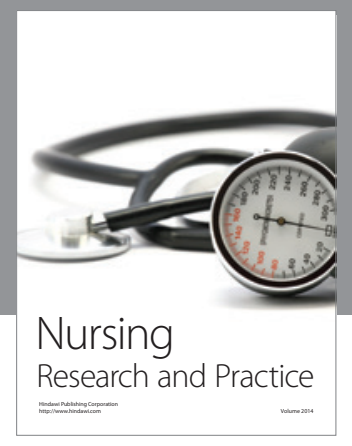

Nursing

Research and Practice

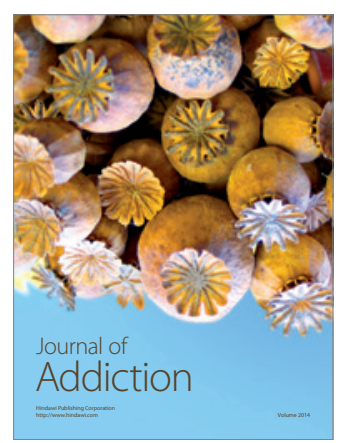

Child Development

Research

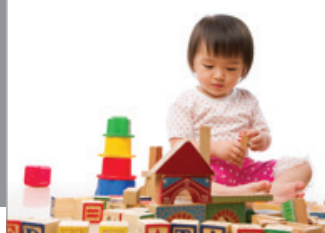

迥
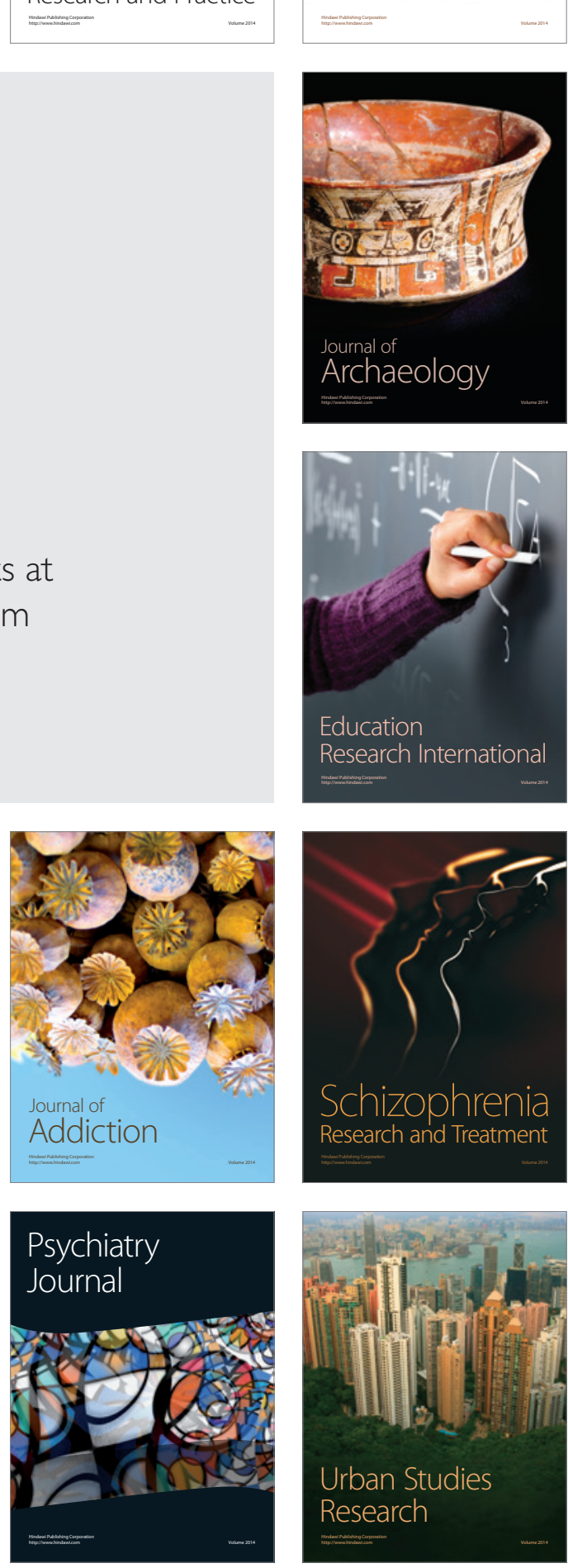